\title{
ЕКСПЕРИМЕНТАЛЬНІ РОБОТИ 3 ЛІТАКОБУДУВАННЯ НА ХАРКІВСЬКОМУ АВІАЗАВОДІ В ДРУГІЙ ПОЛОВИНІ 1930-х - НА ПОЧАТКУ 1940-х pp.
}

У статті проаналізовано діяльність харківського авіазаводу № 135 зі створення нових взірців авіаційної техніки. Відзначено, що упродовж другої половини 1930-х і початку 1940-х рр. на підприемстві кілька разів змінювались головні конструктори і особовий склад конструкторського бюро, що негативно позначилось на його роботі. Головним напрямом проектувальних робіт було створення літаків військового призначення (винищувачів і легких бомбардувальників). Проектування ж цивільних літаків не здійснювалось.

Ключові слова: авіаційний завод, конструкторське бюро, літак, проектування.

Постановка проблели та ї актуальність. У другій половині 1930-х рр. харківський завод № 135, який був найбільшим в Україні підприемством авіаційної галузі, здійснював серійний випуск літаків-розвідників Р-10 (конструктор Йосип Неман), а згодом перейшов до виробництва ближнього бомбардувальника Су-2, спроектованого під керівництвом Павла Сухого. Поряд із серійним виробництвом у конструкторському бюро заводу велось проектування нових взірців авіаційної техніки військового призначення. Жоден із них через різні обставини не був прийнятий на озброєння, однак вивчення їх $є$ важливим для розуміння загальної логіки розвитку авіаційної техніки напередодні німецькорадянської війни.

Аналіз попередніх досліджень. У публікаціях вітчизняних та зарубіжних дослідників основна увага звертається на серійне виробництво літаків на заводі

Харук Андрій Іванович, доктор історичних наук, професор, завідувач кафедри гуманітарних наук, Національна академія сухопутних військ імені гетьмана Петра Сагайдачного, м. Львів.

(C) Харук A.I., 2017 
№ 135, розвиткові ж експериментальних взірців приділено значно менше уваги. Серед робіт, присвячених діяльності конструкторського бюро (КБ) Й. Немана варто відзначити низку публікацій В. Савіна [1; 1]. Роботи КБ П. Сухого розглядаються в дослідженнях М. Гордюкова та Д. Хазанова [3], В. Проклова [4; 5], М. Ришя та А. Кінскі [6], Є. Грущинського та М. Фішера [7]. На певну увагу заслуговують й оглядові праці В. Шаврова [7; 8], хоч у них інформація про експериментальні літаки подана вкрай стисло, а подекуди є неточною (що підтверджуеться сучасними дослідженнями).

Мета та завдання дослідження. Ця стаття має на меті розкрити на основі аналізу як опублікованих праць, так i архівних матеріалів хід розробки експериментальних літаків військового призначення на харківському авіазаводі № 135 в період від середини 1930х до початку 1940-х рр.

Виклад основного матеріалу. В липні 1934 р. рішенням союзного керівництва конструкторське бюро заводу № 135, очолюване Костянтином Калініним, було переведене до Воронежа [10, 10]. Відтоді провідна роль у розробці літаків в Харкові перейшла до КБ Харківського авіаційного інституту (XAI), який очолював профресор Й. Неман. Під його керівництвом ще у 1932 р. був створений пасажирський моноплан XAI-1, який випускався в Києві та Горькому [11, с. 118-119]. Він став основою для літака-розвідника XAI-5, прийнятого на озброєння радянських ВПС під позначенням Р-10. Харківський авіазавод у 1937-1940 pp. виготовив 358 таких літаків, ще 135 випустив завод у Саратові [1, № 4, 26].

Паралельно 3 проектуванням i впровадженням у виробництво літака XAI-5 конструкторське бюро Й. Немана вело роботи над ще кількома проектами літаків-розвідників, які відрізнялись типом силової установки та іншими деталями. Відповідно до звіту від 1 червня 1935 р., дослідний зразок швидкісного розвідника CP-M75 (під мотор M-75) проходив статичні 
випробування; велось ескізне проектування СР-М34ФРН (з мотором М-34ФРН) [12, с. 92]. Однак після успішних випробувань XAI-5 роботи з цих проектів втратили сенс і були припинені.

У 1936 р. конструкторське бюро XAI разом із КБ П. Сухого, Д. Григоровича, С. Кочеригіна, М. Полікарпова та С. Іллюшина взяло участь в конкурсі, оголошеному Управлінням ВПС на кращий моноплан - легкий розвідник i бомбардувальник під умовним девізом «Іванов». При розробці цієї машини керівництво Головного управління авіаційної промисловості (ГУАП) на чолі 3 М. Кагановичем намагалось реалізувати ідею створення т.зв. «наскрізної бригади» зі спеціалістів усіх конструкторських бюро, які мали б розробити єдиний проект. Та настільки радикальна ідея була непідкріпленою організаційно - навіть в рамках адміністративно керованої економіки виявилось вкрай складно, а зрештою - просто нереально координувати зусилля великої кількості елементів. Тому від ідеї «наскрізної бригади» відмовились. Учасниками конкурсу лишились три конструкторських бюро, які мали проектувати три літаки: КБ Сухого створювало суцільнометалевий літак, Полікарпова машину змішаної конструкції, а Немана - дерев'яну [4, c. 2-3]. Та певні елементи стандартизації залишились. Усі три літаки мали отримати низку взаємзамінних вузлів мотоустановку з двигуном AM-34ФРН, шасі й озброєння. Літак КБ Немана отримав шифр «РШ» (інше позначення XАI-7). Провідним конструктором ціеї машини призначили С. Жолковського. Але харківський виявився аутсайдером у цьому змаганні. У зв'язку з труднощами, що виникли при впровадженні у виробництво літака XAI-5, йому було офіційно дозволено на п'ять місяців «заморозити» роботи зі створення РШ [7, с. 74]. Зрештою, макет РШ збудували на одному 3 московських заводів тільки восени 1937 р. Його схвалила комісія ВПС, і в квітні наступного року почалось будівництво дослідного зразка літака. Однак в грудні 1938 р., після арешту Немана за звинуваченням у «шкідництві», всі роботи над РШ припинили [13, с. 33]. 
Іншим напрямом робіт харківського КБ було удосконалення конструкції XAI-5 шляхом встановлення більш потужного двигуна, посилення озброення та внесення низки інших змін. Результатом стала поява літаків XAI-51 і XAI-52. Перший з них отримав мотор М-62 потужністю 800 к.с. Цей дев'ятищиліндровий радіальний двигун повітряного охолодження був (як i M-25B потужністю 730 к.с., який встановлювався на Р-10) створений на основі американського мотора «Райт» «Циклон». Оскільки XАI-51 передбачалось застосовувати як штурмовик, його стрілецьке озброєння суттєво посилили порівняно з попередником: якщо на Р-10 встановлювали тільки два 7,62-мм кулемети ШКАС, то на XАI-51 - сім (два синхронних у фюзеляжі, чотири в крилі і один на турелі MB-5). У бомбовідсіку можна було підвісити чотири 100-кг бомби (на Р-10 - шість 50-кг). 3 огляду на збільшення маси літака дерев'яні лонжерони крила замінили дюралевими; решту елементів конструкції крила й фюзеляжу лишались дерев'яними [1, № 5, 19].

Навесні 1938 р. дослідний зразок XAI-51 вийшов на льотні випробування. Він продемонстрував дещо кращі порівняно з Р-10 характеристики: максимальна швидкість зросла на 30 км/год,, стеля - на 2000 м. Але на початку 1939 р., під час перельоту до Москви для державних випробувань, XAI-51 зазнав ушкоджень i вже не відновлювався.

Новим кандидатом для замін Р-10 став літак XАI-52. Проектування його велось під керівництвом А. Дубровіна, який очолив конструкторське бюро після арешту Й. Немана. XAI-52 отримав наступну варіацію «Циклону» - двигун М-63 потужністю 900 к.с. Постанова Комітету оборони при Раді народних комісарів СРСР № 2 від 5 січня 1939 р. зобов'язувала завод № 135 до 15 лютого 1939 р. представити на випробування дослідний зразок XAI-52, а вже до 1 липня слід було виготовити передсерійну партію (10 літаків), після чого приступити до серійного виробництва і до кінця 1939 р. випустити не менше 100 XAI-52, враховуючи в цю кількість i 
передсерійну партію [14, с. 1]. Паралельно велось проектування літака під позначенням «521» - варіанта XAI-52, у конструкції якого замість сосни використовувались бамбук і піхта, а обшивки з березового шпону замінялась обшивкою 3 соснового [15, с. 268]. Однак невдовзі на програмі створення XAI-52 був поставлений хрест. Поява ближнього бомбардувальника ББ-1 (пізніше перейменованого у Су-2), створеного під керівництвом П. Сухого для участі в конкурсі «Іванов», зробила XАI-52 просто зайвим. У березні 1939 р. Комітет оборони ухвалив рішення перевести харківський завод № 135 i саратовський № 292 з випуску $\mathrm{P}$-10 на виробництво ББ-1 [7, с. 77]. Чергова постанова Комітету оборони від 29 липня 1939 р. зобов'язувала в півторамісячний термін перевести з Москви до Харкова колектив КБ П. Сухого і передати йому усю дослідну базу заводу № 135. Ця ж постанова припиняла підготовку до виробництва XАI-52 [16, с. 1-4].

Головним завдання прибулого до Харкова колективу конструкторів був супровід впровадження ББ-1 в серійне виробництво. Поряд із тим КБ отримало низку завдань 3 перспективного проектування. Затверджений 25 липня 1939 р. план дослідного літакобудування на 1939-1940рр. визначав для КБ заводу № 135 наступні завдання:

- будівництво варіантів ББ-1 під двигуни М-88 і М-63ТК (серійні ББ-1 обладнувались двигунами М-87);

- проектування i виготовлення дослідного зразка удосконаленого штурмовика-бомбардувальника ББ-2 3 мотором М-88;

- підготовка ескізних проектів одномоторного двомісного бомбардувальника i одномоторного одномісного броньованого штурмовика як подальший розвиток ББ-1;

- проектування i виготовлення двох дослідних екземплярів одномісного винищувача, озброєного гарматами [4, с. 8-9].

Ці завдання були конкретизовані двома постановами Комітету оборони від 29 липня 1939 р. Постанова № 228cс 
передбачала створення модифікацій ББ-1, обладнаних двигунами із турбокомпресорами М-63ТК і М-88ТК [17, с. 1]. Постанова № 244cс ставила завдання проектування i будівництва одномоторного одномісного винищувача 3 гарматним озброєнням. Перший екземпляр цієї машини 3 мотором М-105П і турбокомпресором ТК-2 мав бути готовий в березні 1940 р., а другий (з мотором М-106П і турбокомпресором ТК-2) - в липні 1940 р. [18, с. 1].

Винищувач отримав позначення I-135. Він мав змішану конструкцію (дерев'яний фюзеляж 3 франерною обшивкою і металеве крило). Встановлений на I-135 двигун M-105П розвивав потужність 1050 к.с. і обладнувався двома турбокомпресорами ТК-2. Винищувач озброювався однією 20-мм гарматою ШВАК (стріляла через вал гвинта) і двома 7,62-мм синхронними кулеметами ШКАС [6, с. 7576]. Оскільки в СРСР на той час було обмаль досвіду в галузі створення мотоустановок із турбокомпресорами, на заводі № 135 збудували спеціальний стенд для випробувань такої установки [5, с. 10].

Крім виконання робіт, передбачених постановами Комітету оборони, П. Сухий в ініцативному порядку підготував ескізний проект винищувача під мотор М-120 3 турбокомпресором. Характерною рисою цього проекту було розташування двигуна за кабіною пілота. 4 листопада 1939 р. цей ескізний проект затвердив начальник Управління ВПС Я. Смушкевичем. Та на початку 1940 р. через проблеми з доопрацюванням двигуна M-120 (перші його працездатні екземпляри з'явились тільки в 1942 р.) створення винищувача під такий двигун виключили 3 плану дослідних робіт [19, с. 28-29].

Цікаву інформацію щодо експериментальних робіт, які проводились на харківському авіазаводі, містить звіт дослідно-конструкторського бюро цього підприемства за 1939 р. У ньому перераховано близько десяти позицій. Дві 3 них - це «спадок» попереднього складу КБ (літаки XAI-51 i XAI-52, програми створення яких були закриті у 1939 р.). Решта - нові вироби колективу П. Сухого: модифікації бомбардувальника ББ-1 (замовлення №№417 i 452), 
винищувачі із двигунами М-105П-ТК i M-106П-ТК (замовлення № 330 i 360), одномісний броньований штурмовик ОБШ з мотором М-71 (замовлення № 916) [20, с. 54]. Однак жоден із цих проектів не був завершений у Харкові. Причиною стали суб'єктивні чинники. Переведені 3 Москви КБ П. Сухого (63 особи) і сам головний конструктор на новому місці зіткнулись 3 не облаштованістю побуту i мріяли про повернення до столищі. Зрештою П. Сухому вдалось досягти свого. В березні 1940 р. Комітет оборони ухвалив рішення про переведення його КБ до Москви, а точніше, до підмосковного Калінінграда. Тут організовувався новий завод «дослідного літакобудування і нульових серій», який отримав № 289 [21, с. 1].

Як же склалась подальша доля літаків П. Сухого, створення яких почалось в Харкові? Винищувач № 330 був готовий наприкінці квітня 1940 р. Залізницею його перевезли на підмосковний аеродром Раменське, де 15 червня відбувся перший політ. Літак № 360 через відсутність двигуна М-106П довелось обладнати мотором М-105П. В січні 1941 р. його у незавершеному вигляді перевезли з Харкова на завод № 289. У грудні 1940 р. винищувачі отримали нові позначення - Су-1 (№ 330) i Су-3 (№ 360). Однак 16 квітня 1941 р. спільною постановою РНК СРСР і ЦК ВКП(б) роботи зі створення Су-1 і Су-3 були припинені [5, с. 11]. Річ у тім, що навесні 1941 р. в СРСР уже були прийняті на озброєння й впроваджувались у серійне виробництво кілька сучасних винищувачів (МiГ-3, Як-1, ЛаГГ-3). Прийняття на озброєння нових літаків цього класу, які не перевищували своїми льотними властивостями тих, що вже випускались, було позбавлене сенсу. Винищувач Су-1 здійснив ще кілька польотів, а Су-3 законсервували. Після початку німецько-радянської війни обидва літаки евакуювали до Новосибірська. Під час перевезення Су-1 зазнав пошкоджень i був списаний, а Су-3 навесні 1942 p. використовувався як літаючий стенд для випробувань турбокомпресорів [5, с. 11-12]. 
Проект одномісного броньованого штурмовика ОБШ теж набув подальшого розвитку. На рубежі 1939-1940 pp. на заводі № 135 виготовили макет цього літака, який 28 січня 1940 p. був схвалений макетною комісією замовника [22, с. 27]. Після переїзду до Калінінграда КБ П. Сухого продовжило проектування цього літака, однак робота затягувалась через перевантаження конструкторського колективу іншими проектами та проблеми 3 доопрацюванням призначеного для ОБШ двигуна М-71. Перший політ дослідного екземпляра штурмовика, який в грудні 1940 р. отримав позначення Су-6, відбувся тільки 1 березня 1941 р. Робота з удосконалення Су-6 тривала до 1944 р. Було створено кілька його двомісних варіантів, які відрізнялись типом двигуна й іншими деталями, але, зрештою, цей штурмовик так і не прийняли на озброення [22, с. $28-33]$.

Після повернення П. Сухого до Москви на заводі № 135 залишилось конструкторське бюро, очолюване П. Грушиним. Самостійний статус КБ Грушина був наданий наказом Народного комісаріату авіаційної промисловості № 484c від 8 серпня 1940 р. (до цього головним конструктором номінально залишався П. Сухий). Цим же наказом новому керівнику доручалось спроектувати літак (але без конкретизації - який саме) i до 1 жовтня 1940 р. представити його ескізний проект [23, c. 109]. Одночасно Грушин продовжував доопрацювання ближнього бомбардувальника ББ-МАІ, спроектованого ще в Москві, де конструктор працював в Московському авіаційному інституті. Цей одномоторний двомісний моноплан мав оригінальну як на той час конструкцію шасі з носовим колесом (ББ-МАІ став першим літаком в Свропі, обладнаним таким шасі). ББ-МАІ проходив випробування i планувалось його впровадження $\mathrm{y}$ виробництво на Саратовському авіазаводі. Однак, зрештою, від цього відмовились через не досить високі льотні дані машини. Дослідний екземпляр ББ-МАІ знаходився на заводі № 135 і був знищений під час німецько-радянської війни [24, с. 38-40]. 
5 червня 1940 р. постановою Комітету оборони № 243cс конструкторському бюро заводу № 135 доручалось створення ближнього бомбардувальника ББ-4, а планами дослідних робіт на 1941 р. передбачалось доручити проектування двомоторного одномісного винищувача під мотори АМ-37 [25, с. 163-165]. Виготовлення дослідного зразка винищувача, який отримав позначення $\Gamma \mathrm{p}-1$, завершилось в червні 1941 р. До жовтня він випробовувався у Льотно-випробувальному інституті, однак подальші роботи 3 доопрацювання літака припинили у зв'язку зі складним становищем на фронті, що не сприяло випровадженню у виробництво нових типів літаків [24, c. 53-56].

Підбиваючи підсумки нашого дослідження, можемо стверджувати, що руйнування внаслідок репресій наприкінці 1930-х рр. конструкторського бюро заводу № 135, яке очолював Й. Неман, перешкодило впровадженню в серійне виробництво нових літаків власної конструкції. Спроба перевести до Харкова КБ П. Сухого, зрештою, завершилась невдачею - цей конструкторський колектив пропрацював на заводі № 135 лише півроку. Тільки в серпні 1940 р. на підприемство був призначений новий головний конструктор - П. Грушин, під керівництвом якого розгорнулись роботи з проектування нових літаків. Однак через початок німецько-радянської війни до серійного виробництва нових зразків справа не дійшла.

Аналізуючи структуру експериментального літакобудування на заводі № 135 в досліджуваний період, можна відзначити одну характерну особливість: у ньому зовсім відсутні літаки цивільного призначення. Це $\epsilon$ красномовним свідченням мілітаризації радянської авіаційної промисловості в другій половині 1930-х рр.

1. Савин В. Деревянная авиащия профессора Немана / В. Савин // Крылья Родины. - 1997. - № 3. - С. 21-23; № 4. - C. 26-29; № 5. - C. 17-19.

2. Савин B. Крылатый сверхсрочник / В. Савин // Моделист-конструктор. - 1989. - № 3. - С. 13-16.

3. Гордюков $H$. Ближний бомбардировщик Су-2/ Н. Гордюков, Д. Хазанов. - М.: Техника-молодежи, 2000. $-88 \mathrm{c}$. 
4. Проклов В. Ближний бомбардировщик Су-2 и его модификации / В. Проклов // Авиация и космонавтика. - 2010. - № 3. - С. 2-19.

5. Проклов В. Истребители Су-1 и Су-3 / В. Проклов // Авиация и космонавтика. - 2010. - № 4. - С. 10-13.

6. Rуњ M. Sowieckie myњliwce wysokoњciowe / M. Rуњ, A. Kicski // Nowa technika wojskowa. - 2005. - № 6. S. 71-76.

7. Gruszczycski J. Program «Iwanow» / J. Gruszczycski, M. Fiszer // Techika wojskowa. Historia. - 2010. № 4. - S. 67-78.

8. Шавров В.Б. История конструкций самолетов в СССР до 1938 г. / В.Б. Шавров. - М.: Машиностроение, $1978 .-576 \mathrm{c}$.

9. Шавров В.Б. История конструкций самолетов в СССР 1938-1950 гг. / В.Б. Шавров. - М.: Машиностроение, 1978. - $440 \mathrm{c}$.

10. Нестеров А.Ф. 75 лет Харьковскому государственному авиационному производственному предприятию / А.Ф. Нестеров, В.С. Савин, А.Ю. Совенко. - К.: ИЦ АэроХобби, 2001. - 40 с.

11. Харук А. Нарис історії авіаційної промисловості України (1910-1980-ті рр.): монографрія / A.I. Харук. Львів: Вид-во Національного університету «Львівська політехніка», 2010. - 304 с.

12. Государственный архив Российской Федерации (далі - ГАРФ). - Ф. 8418. - Оп. 10. - Д. 55.

13. Маслов М. Призрак Р-10 / М. Маслов // Авиациякосмонавтика. - 1996. - № 9. - С. 29-37.

14. ГАРФ. - Ф. 8418. - Оп. 23. - Д. 423.

15. Российский государственный архив экономики (далі - РГАЭ). - Ф. 8328. - Оп. 1. - Д. 1105.

16. ГАРФ. - Ф. 8418. - Оп. 23. - Д. 461.

17. ГАРФ. - Ф. 8418. - Оп. 23. - Д. 465.

18. ГАРФ. - Ф. 8418. - Оп. 23. - Д. 463.

19. Проклов $B$. Инициативные работы. Проекты самолетов-истребителей / В. Проклов // Авиация и космонавтика. - 2010. - № 8. - С. 28-37.

20. РГАЭ. - Ф. 8328. - Оп. 1. - Д. 1216.

21. ГАРФ. - Ф. 8418. - Оп. 24. - Д. 821.

22. Проклов В. Бронированный штурмовик Су-6 и его модификации / В. Проклов // Авиация и космонавтика. - 2010. - № 6. - С. 26-35.

23. ГАРФ. - Ф. 8007. - Оп. 1. - Д. 8.

24. Лиходей B.M. Главный конструктор Харьковского авиазавода / В.М. Лиходей. - Х.: ИД «Райдер», 2007. - 92 c.

25. ГАРФ. - Ф. 8418. - Оп. 25. - Д. 194. 
Надійшла до редколегії 07.02.2017 p.

Рецензент: О.Й. Дел'янюк, доктор історичних наук, професор, проректор з науково-педагогічної роботи, Волинський інститут післядипломної педагогічної освіти, м. Луцьк.

Харук А.И.

ЭКСПЕРИМЕНТАЛЬНЫЕ РАБОТЫ В ОБЛАСТИ САМОЛЕТОСТРОЕНИЯ НА ХАРЬКОВСКОМ АВИАЗАВОДЕ ВО ВТОРОЙ ПОЛОВИНЕ 1930-х - В НАЧАЛЕ 1940-х гГ.

В статье проанализирована деятельность харьковского авиазавода № 135 в области создания новых образцов авиационной техники. Отмечено, что в течение второй половины 1930-х и начала 1940-х годов на этом предприятии несколько раз менялись главные конструкторы и личный состав конструкторского бюро, что отрицательно сказывалось на его работе. Главным направлением проектирования являлось создание самолетов военного назначения (истребителей и легких бомбардировщиков). Разработка же гражданских самолетов не велась вовсе.

Ключевые слова: авиационный завод, конструкторское бюро, самолет, проектирование.

Kharuk A.

EXPERIMENTAL WORK IN AIRCRAFT CONSTRUCTION AT THE KHARKIV AIRCRAFT FACTORY IN THE SECOND HALF OF 1930s - EARLY 1940s

The article analyzes the activities of the Kharkov aircraft factory number 135 on the creation of new models of aircraft. It is noted that during the second half of 1930s and early 1940s the company changed several times chief designers and design office personnel, which adversely affected his work. The main focus of the design work was the creation of military aircraft (fighters and light bombers). Designing of civil aircraft is not carried out.

Keywords: aircraft plant, design office, airplane, aircraft design. 